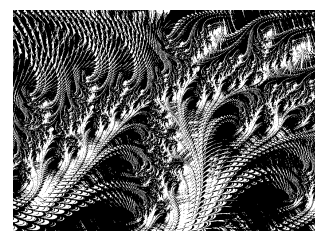

https://doi.org/10.5559/di.30.4.08

\title{
INTERNATIONALISATION IN SCHOLARLY PUBLISHING IN CROATIA THROUGH THE LENS OF BIBLIOMETRIC OVERVIEW OF THE JOURNAL DRUŠTVENA ISTRAŽIVANJA
}

Marina DABIĆ

Faculty of Economics and Business, University of Zagreb, Zagreb, Croatia Jadranka ŠVARC Institute of Social Sciences Ivo Pilar, Zagreb, Croatia Božidar VLAČIĆ Católica Porto Business School and CEGE, Universidade Católica Portuguesa, Porto, Portugal Jasminka LAŽNJAK

Faculty of Humanities and Social Sciences, University of Zagreb, Zagreb, Croatia

UDK: [3:050](497.5):[001.891:311]

Original scientific paper

Received: April 28, 2020

The goal of this research is to shed additional light on the internationalisation of scholarly publishing in Croatia through research based on the bibliometric analysis of the journal Društvena Istraživanja (DI). The first part of this research is dedicated to bibliometric analysis of DI since its conception in 1992, while the second part discusses the internationalisation of scientific journals in Croatia, relying on the critical analysis of relevant literature and the bibliometric characteristics of DI. The results of this research call into question the relevance of the existing scientific publishing policy to contribute to quality research papers and their internationalisation. The research provides implications for both editorial and publishing policies, as well as science policies in general.

Keywords: Društvena Istraživanja, scientific publishing, Croatia, bibliometric overview, internationalisation

Marina Dabić, Faculty of Economics and Business, University of Zagreb, Kennedyjev trg 6, 10000 Zagreb, Croatia. 
Scientific journals play a key role in assessing the quality of scientific research (Macan \& Petrak, 2015) and in the career advancement of researchers becoming a sort of "economic currency" for academics (Grančay et al., 2017). The specific analysis of journals through bibliometric study has attracted attention of scholars and publishers (Jokić, 2005), including those within the social sciences (SS) (Prpić, 2008; Prpić \& Petrović, 2010; Donthu et al., 2020; Valenzuela et al., 2017; Gaviria-Marin et al., 2018).

In many European countries, bibliometric analysis is the basic instrument through which the performance-based funding of research institutions and universities is allocated (Pajić, 2015). Introduced in Croatia in 2013 (GOV, 2013), the implementation of such a system was enhanced more rigorously in 2018 through new research and development (R\&D) funding schemes and through performance contract agreements (GOV, 2018) that brought significant changes in the supporting models of the Croatian scientific journals.

For the Croatian peripheral scientific community with limited research resources, national journals have two important functions: they provide publishing opportunities for the local research community under the "publish and perish" culture, and they provide a counterbalance to the power of Anglophone centres (Dontcheva-Navratilova, 2014). As well as maintaining a national scientific and intellectual base and cultural identity, their role may extend to the international political representation of the country (Bennett, 2014; Salager-Meyer, 2008).

The launch of the new social science journal, DI, along with the establishment of a new institute for applied social research (now the Institute of Social Sciences Ivo Pilar), are marked by specific historic circumstances: the homeland war for independence after the breakdown of Yugoslavia, followed by the dramatic erosion of social and economic activities. When DI entered the high-ranking scientific journal base, Current Contents, this was a huge step forward for Croatia's small research community working within the social sciences. This also held symbolic importance, as it represented international recognition and the emancipation of research published by a newly established state (Jokić et al., 2010). Together with established journals, DI has been assigned an important task in integrating social sciences into the international scientific community.

Many Croatian scientific journals meet the factors of internationalisations which include, among others: a) indexation in most prestigious WOS and Scopus databases, b) geographical orientation - inclusion of foreign authors, c) language 
DRUŠ. ISTRAŽ. ZAGREB GOD. 30 (2021), BR. 4, STR. $807-829$

DABIĆ, M. ET AL.: INTERNATIONALISATION.. openness to English, d) open access publishing, e) international journal's editorial board, f) internationalised review process (Macan et al., 2012; Jokić \& Lasić-Lazić, 2015; Moed et al., 2020; Moed et al., 2021; Macan et al., 2020). However, opinions on the quality and international visibility of the Croatian national journals are conflicting (Petrić, 2011). Open access editorial policy, a centralised quality evaluation system, the central digital base of Croatian scientific journals - Hrčak (Hamster) - initiated in 2006, as well as state funding has enabled scientific publishing in Croatia to flourish, helping Croatia gain a leading position within a large number of domestic journals in comparison to other countries that are similarly on the scientific periphery. Croatia has more journals indexed in international databases such as DOAJ, Scopus, and JCR than most other countries on the scientific periphery, even eclipsing more developed countries, such as Austria and the Republic of Ireland (Hebrang Grgić, 2020).

On the other hand, some believe that a large number of national journals encourages researchers to publish in those journals that are less rigorous in evaluation, less prestigious and, consequently, potentially less visible at an international level (Marušić \& Marušić, 2015; Jokić et al., 2017; Jokić \& Lasić-Lazić, 2015; Marušić \& Marušić, 2014; Zgrabljić et al., 2018; Jokić, 2020). Within some social sciences - sociology in particular - a strong criticism of the parochial and provincial nature of the discipline has emerged (Štulhofer et al., 2010; Prpić \& Petrović, 2010), encouraging the international orientation of research and publishing (Tomić-Koludrović, 2009).

The main incentive for research in this context is the recent analysis of the World Bank (2019), which revealed that Croatia stands out as having the highest number of uncited papers per researcher when compared to all other European countries, despite having a large number of publications in general. According to the latest available data for 2015 (CBS, 2016), about $65 \%$ of Croatian researchers in SS publish scientific contributions either in their own $(30 \%)$ or in other domestic publications (35\%). Besides, analyses of scholarly productivity revealed that Croatian authors used to publish mainly in domestic journals (Jokić et al., 2010) and remained less internationally oriented than most of their Central and Eastern European (CEE) peers (Jokić et al., 2017). These analyses therefore question the relevance of national journals and raise question regarding their internationalisation.

In this context, the purpose of this research is twofold. Firstly, it serves to analyse the importance of DI for the Croatian social science community through a bibliometric analysis of the content produced since it was founded in 1992 and, 
DRUŠ. ISTRAŽ. ZAGREB GOD. 30 (2021), BR. 4, STR. 807-829

DABIĆ, M. ET AL.: INTERNATIONALISATION... secondly, to shed additional light on the internationalisation of scientific publishing in Croatia, using the example of the bibliometric analysis of DI. Following these aims, the research is divided into two parts: the first part focuses on the bibliometric analysis of DI's publications, including citation research and scientific mapping analysis, in order to provide answers to questions such as: 'What is the scientific productivity of DI?'; 'What is DI's thematic focus?'; 'What networks exist between the researchers that publish in DI?'; and 'What is DI's international visibility?'. The second part of this article offers discussions concerning the internationalisation of Croatian scholarly publishing, inspired by the three main questions: 'Are Croatian journals in the social sciences internationally visible?'; 'What can be learned from the bibliometric analysis of DI in terms of the internationalisation of publishing?'; and 'What are the implications for editors and for science policies?'.

The remainder of the article is structured as follows. Following the description of the methodology and dataset (Section 2 ), Section 3 provides the results of the standard bibliometrics of DI and presents the network visualisation analysis with VOSviewer software. The analysis is then expanded, with a discussion of the internationalisation of DI and scholarly publishing in Croatia (Section 4). Finally, Section 5 provides a short summary of the main findings and conclusions of this paper.

\section{METHODOLOGY}

Bibliometric analysis can be defined as "the research field that analyses the bibliographic data with quantitative methods" (Rialp et al., 2019, p. 4) and is usually used to forecast future streams of analysed journals (Dabić et al., 2020). For the purposes of this research, we performed a bibliometric analysis with the assistance of VOSviewer software (Van Eck \& Waltman, 2017). In order to converge all of DI's publications since 1992, we relied on the DI journal publication archives for publications from 1992 to 1994; then the Web of Science by Clarivate Analytics, in which the first issue was indexed in 1994; and then Scopus database by Elsevier, where DI has been indexed since 1996. The academic community considers the Web of Science and Scopus databases to be among the main academic databases, upholding the highest quality standards (Valenzuela et al., 2017). We retrieved both databases, considering all of the documents that had been published in DI since it was founded, and these were identified by running a search query for the keyword "Društvena istraživanja" in the source title. The bibliometric overview provides an analysis of the publication trends and citation structures of DI articles between 1992 and 
DRUŠ. ISTRAŽ. ZAGREB GOD. 30 (2021), BR. 4, STR. 807-829

DABIĆ, M. ET AL.: INTERNATIONALISATION...
2019; the journal's most productive authors, institutions, and countries; as well as journals citing DI articles. The major themes discussed in DI are highlighted based on the co-occurrence of author keywords. Mapping the co-occurrences of author keywords enables researchers to identify the core of the research paper and pinpoint the links between research themes (Kiessling et al., 2021). The discussion of the internationalisation of Croatian scholarly publishing is based both on the critical qualitative analysis of the theoretical concepts and empirical studies drawn from existing literature, and on the bibliometric analysis of DI related to its international orientation.

\section{PERFORMANCE OF DI: PUBLISHING TRENDS AND SCIENTIFIC MAPPING ANALYSIS}

Since its conception DI has pursued notable growth and development, publishing around 1,100 research articles, 432 book reviews, and over 100 other contributions. Seeking thematic and disciplinary openness, the journal welcomes research articles from various social and humanistic disciplines: sociology, psychology, political science, history, law, economics, demography, and linguistics, among others. The journal is recognised in academia and is indexed in prestigious databases such as: Web of Science, Social Sciences Citation Index, Current Contents, Social and Behavioral sciences (Clarivate Analytics), and Scopus (Elsevier), ${ }^{1}$ among others.

The journal is published by the Institute of Social Sciences Ivo Pilar and funded to a greater extent by the Ministry of Science, than by the Institute, donations and the sale of issues. DI is published on a quarterly basis and records the highest number of publications from 1995 to 2013, peaking in 1995 and 1996 with over 90 contributions per year (see Figure 1).

Researchers' interest in publishing in DI is relatively large, and the journal receives over 200 submissions a year. Given that in the period from 2011 to 2019 an average of about 30 scientific articles are published per year, this ratio allows for a relatively rigorous selection process and a high rejection rate of manuscripts, which was in this period over $80 \%$ of submissions (Pilar, 2019). DI provides open access to the journal's complete content as well as another 180 journals in Croatia currently supported by public funds (Macan et al., 2020). The number of papers published in DI in English has been steadily increasing in the last decade, from $19 \%$ in 2009 to $59 \%$ in 2019 (Pilar, 2019).

The accomplishments of DI are rather satisfactory as it records continuous growth in its number of citations, as presented in Figure 1. 


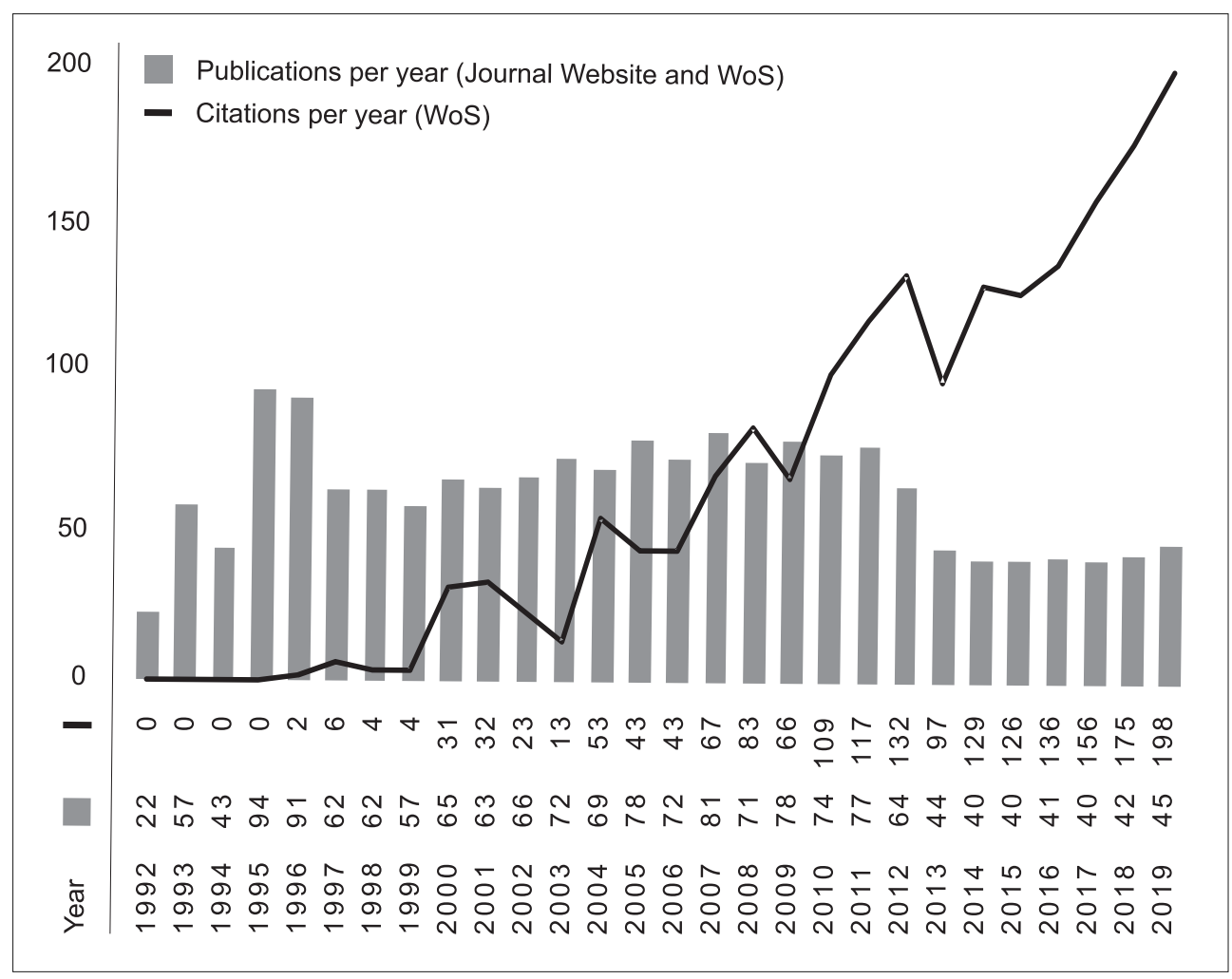

(1) FIGURE 1

Number of DI

Publications and Citations per year, 1996 to $2019^{2}$
The increasing number of citations has resulted in the growing international recognition of DI in terms of the overall growth of its impact factors (IF) by WoS (Web of Science) ${ }^{3}$ and SJR (SCImago Journal Rank) ${ }^{4}$ (Figure 2), ${ }^{5}$ which achieved an IF value of 0.491 in 2019 and 0.190 for SJR respectively.

However, the average citation per article for the investigated period (1996-2019) was approximately 1.14 according to WoS database, meaning that only $39 \%$ of the published articles were acknowledged by the academic community through citations. Within the fields of 'social issues' and 'sociology', DI is ranked among Quartile 4 level journals at a rather low 42nd and 142nd place. These results are evidence of DI's lack of prominence within the respective research areas outside of Croatia, which could be partially explained by DI's predominance of publishing academic contributions in Croatian language (see Figure 2).

In order to graphically represent DI's most frequently published and notable authors (see Table 1), and perceive the ways in which they were linked to each other, Figure 3 presents the results of a co-citation analysis of authors. It is worth noting that the size of the circle indicates the number of times an author has been cited in DI. Prof. H. Eysenck, in line with Prof. G. Milas and R. McCrae, represent the most cited authors. 


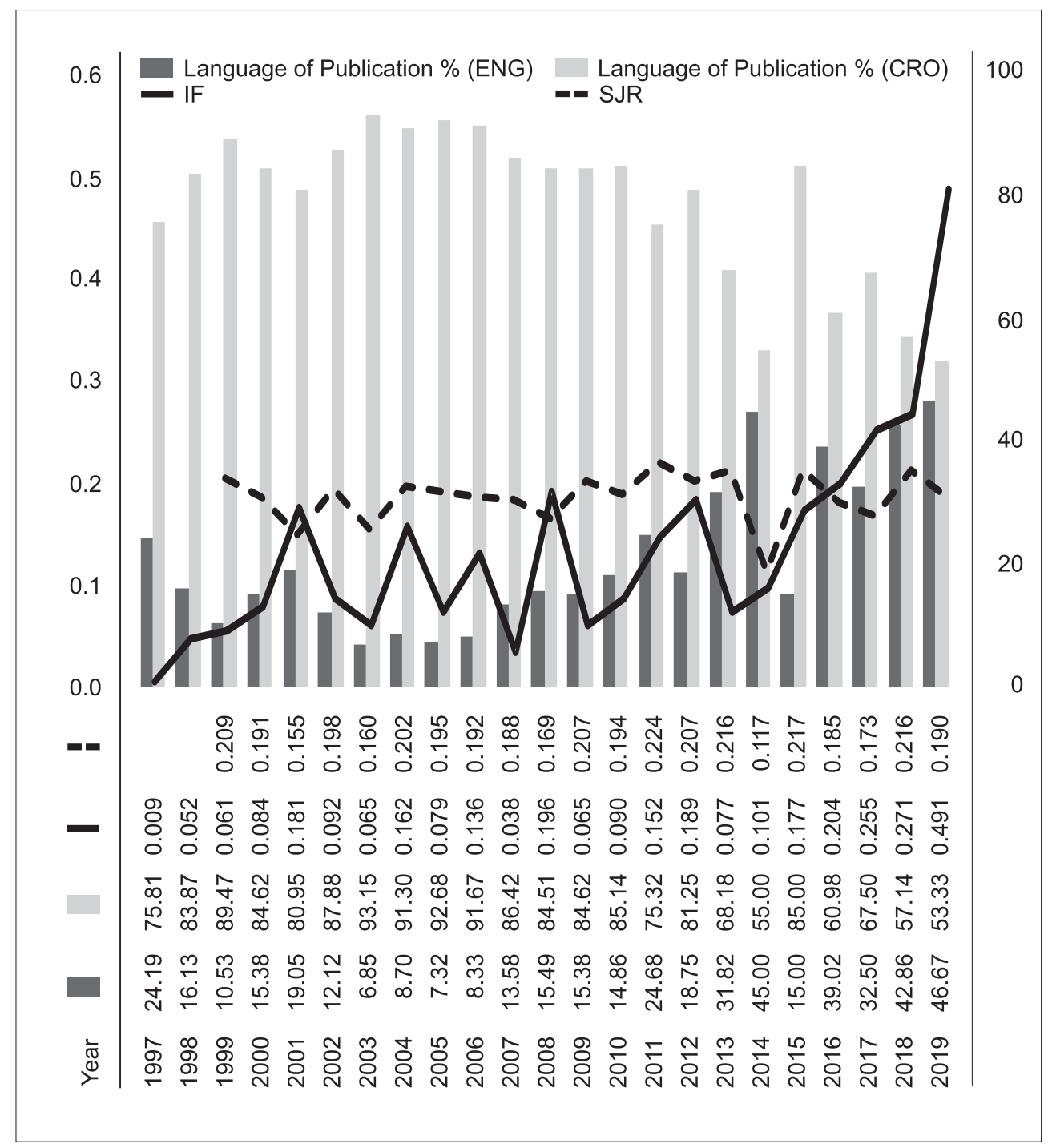

( FIGURE 2

Overview of DI's international scientific indicators ranking and language of publications
Note: At the time of extraction [18/03/2020], IF and SJR indicators were available until 2019.

Abbreviations: IF = Impact factor of the Journal Citation Reports 2019; SJR = SCImago Journal Rank.

Next, the analysis reveals that the most frequently published and influential authors are all from Croatia (Table 1), more precisely from the University of Zagreb and from the Institute of Social Sciences Ivo Pilar - the publisher of the journal (Table 2). Authors affiliated with Ivo Pilar are slightly more successful in visibility, given that their number of citations per paper is higher at 2.02, compared to 1.94 for those at the University of Zagreb (Table 2). 


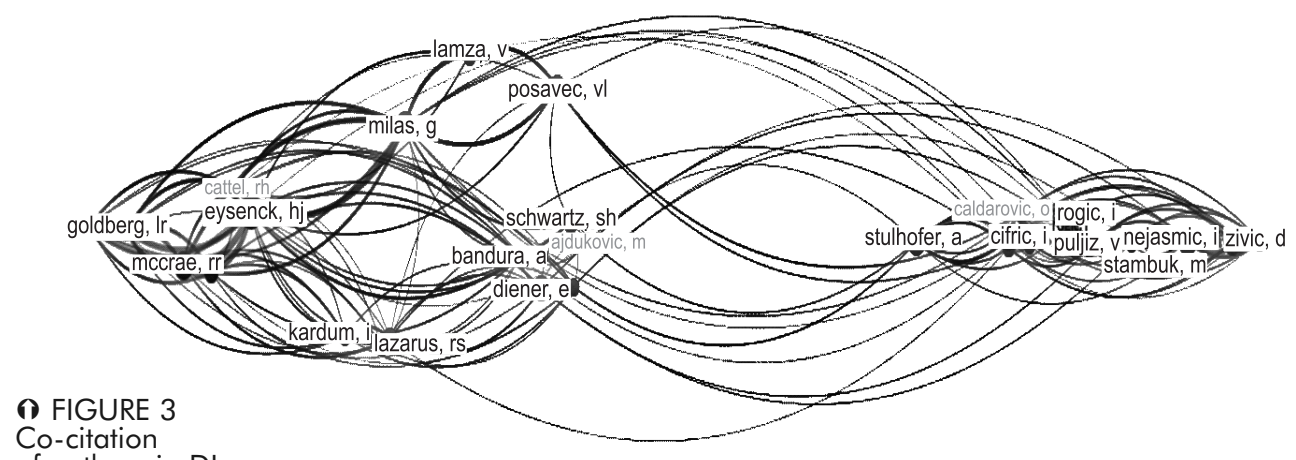

Co-citation

of authors in DI

\begin{tabular}{|c|c|c|c|c|c|c|c|}
\hline $\mathrm{R}$ & Author & $\mathrm{H}$ & Affiliated institution & Country & $\begin{array}{l}\mathrm{TP} \\
\text { Total } \\
\text { (articles) }\end{array}$ & $\begin{array}{l}\text { TC } \\
\text { Total } \\
\text { (self- } \\
\text {-citations) }\end{array}$ & $\mathrm{C} / \mathrm{P}$ \\
\hline 1 & Živić, D. & 5 & Institute of Social Sciences Ivo Pilar & Croatia & $60(16)$ & $52(12)$ & 0.87 \\
\hline 2 & Bejaković. P. & 4 & Institute of Public Finance & Croatia & $28 \quad(5)$ & $10(0)$ & 0.36 \\
\hline 3 & Milas, G. & 7 & Institute of Social Sciences Ivo Pilar & Croatia & $25(22)$ & $75(13)$ & 3.00 \\
\hline 4 & Peračković, K. & 3 & Institute of Social Sciences Ivo Pilar & Croatia & $20(8)$ & $12(2)$ & 0.60 \\
\hline 5 & Polšek, D. & 2 & University of Zagreb & Croatia & $18 \quad(5)$ & $7(0)$ & 0.28 \\
\hline
\end{tabular}

(1) TABLE 1

Five most frequently published authors (all types of documents)
Abbreviations: $\mathrm{R}=$ Rank according to $\mathrm{TP} ; \mathrm{H}=\mathrm{h}$-index according to Web of Science for all scientific contributions by the author at the time of the data collection; $\mathrm{TP}=$ Total publications in DI; TC $=$ Total citations; $\mathrm{C} / \mathrm{P}=$ citations per paper.

\begin{tabular}{|c|c|c|c|c|c|}
\hline $\mathrm{R}$ & Affiliated institution & Country & $\begin{array}{r}\text { Total } \\
\text { publications } \\
(\mathrm{TP})\end{array}$ & $\begin{array}{r}\text { Total } \\
\text { citations } \\
(\mathrm{TC})\end{array}$ & $\begin{array}{r}\text { Citations } \\
\text { per paper } \\
(\mathrm{C} / \mathrm{P})\end{array}$ \\
\hline 1 & University of Zagreb & Croatia & 313 & 607 & 1.94 \\
\hline 2 & Institute of Social Sciences Ivo Pilar & Croatia & 253 & 511 & 2.02 \\
\hline 3 & University of Rijeka & Croatia & 63 & 93 & 1.48 \\
\hline 4 & University of Zadar & Croatia & 49 & 63 & 1.29 \\
\hline 5 & University of Ljubljana & Slovenia & 31 & 59 & 1.90 \\
\hline
\end{tabular}

o TABLE 2

Affiliated institutions of the most frequent published DI authors between 1992 and 2019
Table 3 shows the leading DI authors' affiliated countries. Typically, countries with more affiliated authors have more publications which, in turn, results in a higher number of citations. Croatia and Slovenia lead in all three metrics: number of cited publications, total citations, and citations per contributing author.

Authors of the most cited scientific articles in DI (see Table 4) also come from Croatia, except for the most frequently cited article, whose author, R. A. Amato, is affiliated with Pennsylvania State University, USA. 


\begin{tabular}{llrrrrr}
\hline R Country & $\begin{array}{r}\text { Record } \\
\text { count }\end{array}$ & \% out of 1636 & TC & $\begin{array}{r}\text { Without } \\
\text { self-citation }\end{array}$ & C/P \\
\hline 1 Croatia & 962 & $58.80 \%$ & 1616 & 1176 & 1.68 \\
2 & Slovenia & 64 & $3.91 \%$ & 143 & 140 & 2.23 \\
3 United States of America & 18 & $1.10 \%$ & 50 & 50 & 2.78 \\
4 & England & 10 & $0.61 \%$ & 18 & 18 & 1.8 \\
5 & Germany & 9 & $0.55 \%$ & 9 & 9 & 1.0 \\
\hline
\end{tabular}

Abbreviations available in Table 1.

R Title

Authors

TC Vol (issue), pages, year C/Y

1 The consequences of divorce for adults and children: An update.

Amato, P. R. $\quad 27 \quad 23(1), 5-24,2014$

2 Dynamism in Stability: Religiosity in Croatia in 1999 and 2008

Črpić, G.;

Zrinščak, S

20 19(1/2), 3-27, 2010

3 Depopulation of counties and disparity in the regional development of Croatia

Pejnović, D. $\quad 18$ 13(4/5), 701-726, 2004

4 Changes in the dynamics and distribution of the displaced-refugee contingent in Croatia from mid-1991 to mid-1998

Živić, D.

17 8(5-6), 767-791, 1999

5 Life satisfaction in adolescents: The effects of perceived family economic status, self-esteem and quality of family and peer relationships

Raboteg-Šarić, Z.;

Brajša-Žganec, A.;

Šakić, M. 16 18(3), 547-564, 2009

DO TABLE 3

Countries most commonly affiliated with DI authors, 1992-2019

(1) TABLE 4

Five most cited articles published in DI, 1992-2019 according to the WOS
An analysis of the most frequently used keywords in the journal confirms that the journal is thematically oriented towards research in various sub-disciplines of psychology (Table 5 and Figure 4). This can be explained by the endeavours of the editorial policy to publish articles which pursue normative criteria for quality scientific publishing, such as originality, clarity, theoretical significance, sound methodology, and applicability (Chase, 1970). The domination of articles in the field of psychology might be explained by its communication patterns and methodology (especially statistical analyses) that are closer to these normative criteria than articles in other disciplines (Jokić et al., 2010).

The journal's focus on psychology is also confirmed by a list of the most frequently cited journals in DI publications (Table 6). The thematic array of journals citing DI is somewhat broader and includes, in addition to dominant psychology, journals in sociology, economics, and rehabilitation, among other research domains (Table 7 ). 
DRUŠ. ISTRAŽ. ZAGREB

GOD. 30 (2021), BR. 4, STR. 807-829

DABIĆ, M. ET AL.:

INTERNATIONALISATION...

TABLE 5

Overview of top 20

author keywords

published in DI
(1) FIGURE 4

Co-occurrence of top 20 author keywords published in DI (Ranking according to the number of occurrences)

\begin{tabular}{lllrr}
\hline & R & Keyword & OC & LS \\
\hline Cluster I & 1 & Croatia & 52 & 9 \\
& 2 & Education & 8 & 2 \\
& 3 & Gender differences & 8 & 1 \\
& 4 & Slovenia & 8 & 1 \\
& 5 & Religiosity & 6 & 1 \\
& 6 & Employment & 6 & 3 \\
Cluster II & 7 & Vukovar & 6 & 1 \\
& 1 & Personality & 12 & 6 \\
& 2 & Quality of life & 8 & 6 \\
& 3 & Academic achievement & 7 & 1 \\
Cluster III & 4 & Well-being & 6 & 2 \\
& 1 & Life satisfaction & 10 & 11 \\
& 2 & Self-esteem & 9 & 8 \\
& 3 & Social support & 6 & 5 \\
Cluster IV & 4 & Subjective well-being & 6 & 3 \\
& 1 & Adolescents & 18 & 9 \\
& 2 & Personality traits & 12 & 5 \\
& 3 & Gender & 7 & 1 \\
Cluster V & 1 & Depopulation & 7 & 5 \\
& 2 & Emigration & 6 & 4 \\
\hline
\end{tabular}

Please note that ranking is according to OC.

OC $=$ Number of occurrences; LS = Link strength.

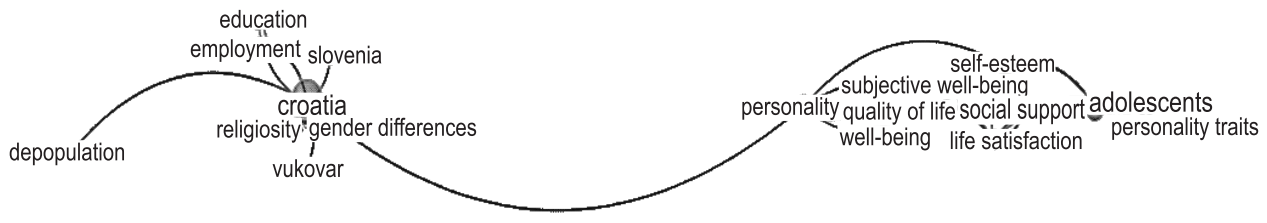

- TABLE 6 Most cited Journals by DI (without self-citation), 1992-2019

\begin{tabular}{llrrr}
\hline $\mathrm{R}$ & Journal & TC & CLS & IF \\
\hline 1 & $\begin{array}{l}\text { Journal of Personality } \\
\text { and Social Psychology }\end{array}$ & 704 & 9753 & 6.315 \\
2 & $\begin{array}{l}\text { Personality and } \\
\text { Individual Differences }\end{array}$ & 345 & 5247 & 2.310 \\
3 & Child Development Perspectives & 266 & 3106 & 4.636 \\
4 & Journal of Marriage and Family & 263 & 3568 & 2.215 \\
5 & Psychological Bulletin Journal & 248 & 3779 & 20.838 \\
\hline
\end{tabular}

Ranking according to TC - Times Cited. Abbreviation: CLS - Co-citation link strength. IF according to the last available year (2019). 
$\rightarrow$ TABLE 7

Journals which

cited DI the most

(without self-citation),

1992-2019

\begin{tabular}{llrr}
\hline R & Journal & TPC & IF \\
\hline 1 & Revija za Socijalnu Politiku & 40 & 0.406 \\
2 & Ljetopis Socijalnog Rada & 38 & 0.316 \\
3 & Croatian Journal of Education & 25 & 0.310 \\
4 & Croatian Medical Journal & 11 & 0.333 \\
5 & Frontiers in Psychology & 9 & 2.067 \\
\hline
\end{tabular}

* Ranking according to TPC - Times Papers (published in DI). IF according to the last available year (2019).

\section{INTERNATIONALISATION OF DI AND SCHOLARLY PUBLISHING}

A journal may be considered internationally relevant if it is included in international bibliographic and citation databases such as WoS/JCR and Scopus/SCImago, especially in the long term, and if the five-year impact factor is at least in the third quartile (Jokić \& Lasić-Lazić, 2015). In this respect, apart from quartiles, Croatian journals are doing quite well.

Previous bibliometric analyses have revealed that, in 2012, 57 Croatian journals were indexed in WoS/JCR and, of these, 11 or $19.2 \%$ were in the field of social science. According to Macan et al. (2020), there were only 16 Croatian journals indexed by WoS in 2007; in 2011, they indexed 61 journals and their current number is 124 in the Web of Science Master Journal List in 2020. Data shows that Croatia has the highest number of journals in WoS/JCR and Scopus/SCImago Journal Ranking, compared to $10 \mathrm{EU}$ countries similarly operating within the scientific periphery, but also compared to some more developed countries, such as France, Italy, and Spain (Jokić \& Lasić-Lazić, 2015).

A sharp increase in the number of Croatian journals, as well as in other Eastern European countries, came in 2009 and 2010, when the WoS and Scopus databases notably expanded their coverage and opened their doors to countries on the scientific periphery in the interest of regional equality (Jokić \& Lasić-Lazić, 2015; Pajić, 2015; Jokić et al., 2010; Macan et al., 2020). According to recent analyses (Hebrang Grgić, 2020), the number of Croatian journals in JCR over the last 10 years is about 40 , and Croatia remains one of the leading countries in terms of the number of journals listed in the JCR database. By comparison, in 2018, Croatia had 40 journals in the JCR and Bosnia and Herzegovina had 1, Slovenia had 19, Ireland had 28, Hungary had 37, and Austria had 39 (Hebrang Grgić, 2020). By 2005, only three Croatian journals (International Review of Aesthetics and Sociology of Music, Collegium Anthropologicum, and Journal of General Social Issues (Društvena Istraživanja) were indexed by WoS, SSCI, and A\&HCI (Jokić et al., 2012). 
DRUŠ. ISTRAŽ. ZAGREB GOD. 30 (2021), BR. 4, STR. 807-829

DABIĆ, M. ET AL.: INTERNATIONALISATION...
Due to the new "geopolitical" expansion policy of WoS, the number of publications in WoS journals by authors from Eastern European countries has grown impressively by more than $140 \%$ on average between 2009 and 2013, compared to the period from 2004 to 2008, and Croatia doubled its number of published articles. This demonstrates a high correlation between the numbers of published articles and the number of indexed national journals (Pajić, 2015). However, the relationship between the number of journals indexed in WoS and Scopus, scientific productivity, and the international recognition of publications is not straightforward.

A relatively large number of Croatian journals listed in WoS does not mean that publications in these journals are internationally relevant and visible. Data on cited and uncited publications per researchers (in FTE - full-time equivalent) show that Croatia is somewhat above average in terms of cited papers, but that the country also has the highest number of uncited publications when compared to other EU countries (World Bank, 2019). Social sciences make up the largest share of uncited publications and their proportion of cited publications has been declining (World Bank, 2019, p. 65). This suggests overproduction and a lack of relevance of publications, especially in the SS, and points to the inefficiencies of the research system and corresponding scientific policies in general.

The standard excuse in Croatia for the low quality of scientific publications is insufficient investment in R\&D. These investments, as measured by Gross expenditures on R\&D (GERD), are unacceptably low (0.86 of GDP in 2017 and 0.97 of GP in 2018 ), but the ratio of average citations per publication to GERD is among the lowest in Europe. Poland, Slovakia, and Lithuania have higher citations per publication with a lower average GERD (World Bank, 2019, p. 54). A similar and troublesome relationship ratio has been seen between public funds and scientific publications, with among $10 \%$ of the most cited publications measured by the European Innovation Scoreboard (EIS, 2018). Better scientific outputs with similar or smaller public investment in science (Figure 5) are produced in Bulgaria, Romania, Hungary, Poland, Slovakia, and Slovenia, meaning that Croatia underperforms most of its CEE peers (Račić \& Śvarc, 2020).

Reasons for the poor international visibility of Croatian scholarly publishing can be divided in two groups. The first group pertains to the "culture of publishing" of Croatian authors, and the second group concerns the specific character of the national journals included in the international citation databases (WoS and Scopus). 


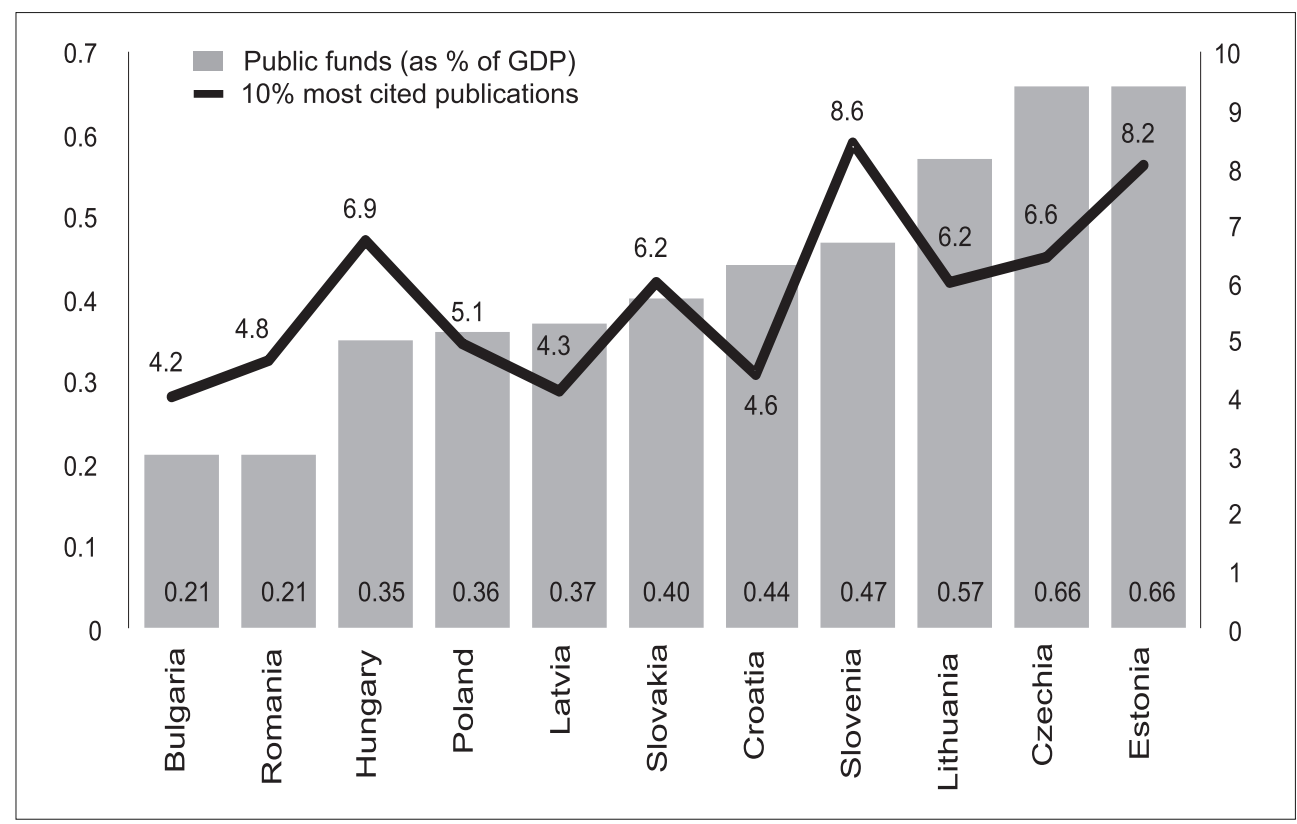

Source. Račić \& Švarc, 2020.

(1) FIGURE 5

Comparison between public funds for R\&D and share of scientific publication in the top $10 \%$ of the most cited publications, 2019
The available data suggests that the culture of publishing of Croatian authors in the domain of social sciences is strongly determined by weak internationalisation, i.e., by the tendency of scholars to publish their research in national journals indexed by WoS or Scopus (Macan et al., 2012). An analysis of Croatian scholarly productivity during the fifteen-year period between 1991 and 2005 (Jokić et al., 2010) revealed that $77.6 \%$ of the total number of Croatian social science papers were published in two national journals: Collegium Antropologicum and Društvena Istraživanja. A more recent analysis (Jokić et al., 2017) shows that, almost fifteen years later, this tendency has not changed much: the analysis shows that, in the group of European post-socialist countries, Croatian authors are less internationally oriented than researchers from Slovenia, Estonia, Hungary, and Lithuania. These countries publish their papers in the more prestigious journals of Western countries, dominated by journals from the UK, the Netherlands, and Germany, while Croatian authors prefer to publish their papers in the Croatian journals of Croatia and other CEE countries journals. The only difference nowadays is that authors have a larger number of Croatian national journals included in WoS (Macan et al., 2020) in which they can publish their works. Croatian scientists working in the social sciences are not alone in their practices, as the majority of CEE countries, Latin American nations, China, Spain, South Africa, among others, prefer to publish in national journals (Moed et al., 2020; Moed at al., 2021). 
DRUŠ. ISTRAŽ. ZAGREB GOD. 30 (2021), BR. 4, STR. 807-829

DABIĆ, M. ET AL.: INTERNATIONALISATION...

(1) TABLE 8 Impact Factor of Croatian Journals indexed in SCIE and $\mathrm{SSCl}$ in 2019
It is expected that inclusion into the WoS databases make Croatian journals and publications more internationally visible and more open to the world's scientific community. However, the fact that Croatia stands out, with the highest number of uncited papers per researcher in Europe, says the opposite. This raises questions regarding the distinctive features of Croatian journals which make them, despite indexation in WoS or Scopus, poorly visible internationally.

A distinctive feature of all Croatian journals in the social sciences (and in many other disciplines) indexed by the WoS is that, for the majority of them, IF does not exceed the value of 0.5 , placing them into the fourth quartile (Table 8). More precisely, Croatian journals are at the bottom of the list of indexed journals (Jokić \& Lasić-Lazić, 2015) like many CEE journals and, alongside these journals, they possess high numbers of non-cited papers (Jokić, 2020) or low-cited papers (Jokić et al., 2012; Zgrabljić Rotar et al., 2018), which is further indicated by a low Eigenfactor.

\begin{tabular}{llrrr} 
R. & Journal Title & TC & IF & $\begin{array}{r}\text { Eigenfactor } \\
\text { Score }\end{array}$ \\
\hline 1 & Psychiatria Danubina & 1,299 & 0.764 & 0.00199 \\
2 & Economic Research-Ekonomska Istraživanja & 1,168 & 2.229 & 0.00131 \\
3 & Kinesiology & 474 & 1.225 & 0.00080 \\
4 & Društvena Istraživanja & 230 & 0.491 & 0.00009 \\
5 & Revija za Socijalnu Politiku & 78 & 0.406 & 0.00003
\end{tabular}

Ranking according to TC - Times Cited. Abbreviation available in Table 1

Another characteristic of journals in the social sciences indexed in WoS is that the dominant share of authors are from Croatia and many of these authors publish articles in Croatian, around 65\% of articles (Macan et al., 2012, p. 511). Articles in native languages are less frequently cited than papers in English (Moed et al., 2020). The previous analysis of international orientation of the Croatian journals (Macan et al., 2012) measured by INO indicator (a ratio of foreign (co)authors to domestic authors in a journal) (Moed et al., 2002; Moed at al., 2021) revealed strong orientation of the Croatian journals towards Croatian authors. The INO indicator of DI reached $89.9 \%$ while "[A] purely national journal would have an INO value of 100 per cent..." (Moed et al., 2002 , p. 2). According to Macan et al. (2012, p. 516) only 4 out of 25 analysed journals which were indexed in WOS SSCI and A\&HCI in 2008-2010 were more internationally oriented than others, with the INO indicator less than 30. These are Kinesiology, Prolegomena, International Review of the Aesthetics and Sociology of Music and Croatian Journal of Philosophy. 
DRUŠ. ISTRAŽ. ZAGREB GOD. 30 (2021), BR. 4, STR. 807-829

DABIĆ, M. ET AL.: INTERNATIONALISATION..
According to the last available data (Macan et al., 2012, p. 511 ), about $65 \%$ of articles in the field of social sciences in the Croatian journal indexed in WOS have been published in English. This raises the question, as concluded by Jokić et al. (2012), of what is actually obtained by indexing national journals in a prestigious citation base if the papers are written in a native language and cannot reach a larger audience.

Finally, another issue arises when we consider the attractiveness and relevance of the national journals for the international scientific community due to "regional segregation". According to Pajić (2015), Eastern European journals in the social sciences, including those in Croatia and excluding those in Hungary and Poland, rely in their scientific productions mostly on regional, language and cultural proximities.

The bibliometric analysis of DI illustrates the distinctive features of Croatian journals which make them, despite indexation in international databases, insufficiently visible internationally. It could be argued that DI is a prestigious journal of high importance for researchers in Croatia, as it is currently the only journal, along with Psychiatria Danubina, indexed in the highly-selective Current Contents database. ${ }^{7}$ Together with Collegium Anthropologicum, DI accounts for a very high proportion of publications in social sciences indexed in WoS-SSCI in the period between 1991 and 2005 (Jokić et al., 2012). DI applies a quality selection process, and the manuscript rejection rate has been over $80 \%$ since 2011 (Pilar, 2019). However, despite its national prominence, it suffers from a low IF (0.491 in 2019) that places it in the fourth quartile in WoS, indicating weak and insufficient international visibility.

The bibliometric analysis points to the three features which are most likely to contribute to this low international visibility: prevalence of Croatian authors (Table 1) and institutions (Table 2) with an international outreach mainly centred in CEE countries. This allows Croatian authors to lead in all three metrics of DI: the number of cited publications, the total number of citations, and citations per contributing author. Furthermore, the share of authors from abroad is modest, comprising around $20 \%$ of the total number of contributors in the last decade, from 2009 to 2019 (Pilar, 2019). The reasons behind the insufficient inclusion of foreign authors are complex and may include, among others, the lack of quality contributions from foreign authors. Subsequently, the share of publications in English has remained at around 50\% since 2013. Finally, the journals citing DI are predominantly national journals from the various fields of social sciences (Table 6).

Scientific mapping analysis further acknowledges the strong connections between DI authors in terms of co-citation, as well 
DRUŠ. ISTRAŽ. ZAGREB GOD. 30 (2021), BR. 4, STR. 807-829

DABIĆ, M. ET AL.: INTERNATIONALISATION... as the ways in which their interest in their country of origin intersects with the fields of psychology and demography. Therefore, it can be concluded that DI reflects the main shortcomings of the Croatian journals well, which make them poorly internationally visible despite their indexation in the international bibliographic databases.

\section{CONCLUSIONS}

This research reveals that international orientations in Croatian scholarly publishing in the social sciences is insubstantial. A relatively large number of Croatian social science journals in the international citation databases, primarily WoS, and an increased number of publications in such journals does not necessarily correlate to the greater international visibility of publications and an improvement in the quality of scientific research and publishing (World Bank, 2019, p. 65; Jokić, 2020; Zgrabljić Rotar et al., 2018). A large number of articles in general have received little or no citation, suggesting that the quality of the scientific publications in Croatia should be improved, especially when compared to countries with similar or lower investments in R\&D. Uncited publications represent missed opportunities for authors to reach wider audiences and contribute to their fields of science internationally (World Bank, 2019). This further implies that some Croatian research endeavours may be irrelevant to the international scientific community. This puts the current policy of Croatian scientific publishing at stake, for publishers and editors, as well as for the science policy of the state.

Drawing on the results of this research, which include a bibliometric analysis of DI and a critical review of existing literature, the following reasons for poor citation rates and lack of international visibility can be identified:

- Many researchers choose to publish their research in national journals included in international databases, such as WoS. In doing so, they formally meet the criteria for international recognition and for their individual scientific promotion, as prescribed by the Ministry of Science. However, the low international visibility of journals themselves, as a result of weak scientometric characteristics (low IF and quartile, low prominence) prevent these publications from obtaining a wider international impact and increased visibility.

- Many articles in national journals included in WoS are published in Croatian, which greatly impedes their outreach to potential audiences. This conclusion corresponds with previous findings that show that articles published in prominent international journals in English are distinctly more visible to the academic community (Zgrabljić Rotar et al., 2018). 
DRUŠ. ISTRAŽ. ZAGREB GOD. 30 (2021), BR. 4, STR. $807-829$

DABIĆ, M. ET AL.: INTERNATIONALISATION..
- Co-citation analyses of DI suggest that the journal receives attention mainly at regional and national levels, which probably depends on language and geographical proximity (Pajić, 2015; Marušić \& Marušić, 2015).

In addition to the strong domestic orientation of authors and institutions, the low international visibility of Croatian journals might result from the insufficient interest of foreign prominent authors to publish in our domestic journals and the consequent editorial parochialism. It can also be assumed that local authors often send their quality papers to journals published by more prominent international publishers.

This research confirms some previous findings that the inclusion of a journal in relevant world citation databases, such as WoS or Scopus, represents only potential visibility, which is conditional on whether or not there is a language barrier, whether or not the text is fully accessible, and whether or not the topic is of interest to the wider scientific community (Jokić et al., 2012). While journals not indexed in these two databases are outside of mainstream scientific communications, nationally oriented journals entering WoS or Scopus do not automatically become more international.

Historically, domestic journals have played a significant role in the formation of Croatian science, providing useful contributions to scientific policies and establishing a unique system of scholarly publishing among CEE dating back to 1980. This has involved the public funding of scholarly journals, enabling them to flourish. Today, however, it is not entirely clear whether or not such policies are beneficial to Croatian science or not (Marušić \& Marušić, 2015), as various groups' interests have, over time, outgrown national interests. A great number of domestic journals give the possibility for researchers to (mis) use domestic journals to formally fulfil the requirement for the international visibility of their publications without increasing the quality of their research and their exposure to international competition (Marušić \& Marušić, 2015; Pajić, 2015).

Many will argue that the social sciences remain bounded by national borders and discourses that are limited by specific research subjects and national priorities (Petrić, 2011), justifying low international visibility. Such knowledge can be truly irrelevant to international journals, which are usually dominated by Anglo-American publishers or editors. Although some subjects are indeed of local relevance, it is important to remember that science is global and that problems discussed by the social sciences today increasingly surpass national borders (Tomić- Koludrović, 2009). The number of Croatian journals in 
DRUŠ. ISTRAŽ. ZAGREB GOD. 30 (2021), BR. 4, STR. 807-829

DABIĆ, M. ET AL.: INTERNATIONALISATION...
WoS and Scopus, which outpace many other countries (both peer countries and those that are more developed), suggests that a good balance between local scholarly journals and international ones should be established to prevent the misuse of public funding of journals that do not contribute to the body of scientific knowledge, either locally or internationally.

\section{IMPLICATIONS AND LIMITATIONS}

Opinions regarding national journals, including those indexed in citation databases such as WoS, and their role in stimulating quality research in Croatia and international recognition are inconclusive and conflicting. The findings of this research suggest that a greater international visibility of Croatian authors' publications depends on at least two factors: the larger number of publications in internationally influential journals and the stronger orientations of domestic journals towards internationalisation.

This has important implications for science policies, as increased international recognition of publications can be achieved through evaluation systems which recognise publishing in prestigious international journals (e.g quartile 1 and 2) for both the scientific promotion of individual researchers and the funding of research institutions. A significant step in this direction has already been established by the new performance-based programme contracts (GOV, 2018).

The consequences for scientific policies also have implications for journal editors and publishers, as these findings should encourage them to act in order to improve their international visibility. How a journal frames itself - whether it will be mostly 'domestic' in terms of its language, scope, and authors - completely depends on the 'political decisions' of publishers which, in Croatia, mainly consist of universities, public institutions, and professional associations (Jokić \& Lasić-Lazić, 2015). Preservation of national culture and language as well as the need to disseminate research of local relevance may strongly and justifiably influence such publishers' decisions. Although such journals can hardly compare to prestigious global publishers (e.g., Sage, Oxford Press, Springer, Elsevier, Emerald, Taylor Francis, etc.) who have years of professional and commercial experience in scientific publishing, they can certainly work towards improving their international visibility.

Finally, some scholars may argue that this research puts too strong of an emphasis on the quantitative bibliometric features of publishing, which leads to the widespread frustration and dissatisfaction of researchers, especially in the social sciences (Grančay et al., 2017). Although this could be 
DRUŠ. ISTRAŽ. ZAGREB GOD. 30 (2021), BR. 4, STR. 807-829

DABIĆ, M. ET AL.: INTERNATIONALISATION... recognised as a limitation of this research, recent analysis (Jokić \& Lasić-Lazić, 2015) suggests an equal importance of journals as mediums of communication in the field of social science. This certainly justifies the use of bibliometric methods in evaluating the international orientation of journals in the social sciences.

\section{NOTES}

\section{REFERENCES}

${ }^{1}$ http://drustvena-istrazivanja.pilar.hr/index.php/drustvena-istrazivanja/ about/editorialPolicies\#custom- 0

${ }^{2}$ Data available at Web of Science [accessed on 18/03/20]

${ }^{3}$ https://jcr.clarivate.com/

${ }^{4}$ https://www.scimagojr.com/

${ }^{5}$ At the time of extraction, the data was available only for the period from 1997 to 2019.

${ }^{6}$ For more information regarding Eigenfactor please see: https://clarivate.com/webofsciencegroup/article/closer-look-eigenfactor-metrics/

7 http://lib.irb.hr/web/hr/vijesti/item/2099-hrvatske_casopisi_u_woscc i_cc.html

Bennett, K. (Ed.) (2014). The semiperiphery of academic writing discourses, communities and practices. Palgrave Macmillan. https://doi.org/10.1057/ 9781137351197

CBS (2016). Research and development, 2015. No. 8.2.1. Croatian Bureau for Statistics.

Chase, J. M. (1970). Normative criteria for scientific publication. The American Sociologist, 5(3), 262-265.

Dabić, M., Vlačić, B., Paul, J., Dana, L. P., Sahasranamam, S., \& Glinka, B. (2020). Immigrant entrepreneurship: A review and research agenda. Journal of Business Research, 113, 25-38. https://doi.org/10.1016/j. jbusres.2020.03.013

Dontcheva-Navratilova, O. (2014). The changing face of Czech academic discourse. In K. Bennett (Ed.), The semiperiphery of academic writing discourses, communities and practices (pp. 39-61). Palgrave Macmillan. https://doi.org/10.1057/9781137351197_3

Donthu, N., Kumar, S., \& Pattnaik, D. (2020). Forty-five years of Journal of Business Research: A bibliometric analysis. Journal of Business Research, 109, 1-14. https://doi.org/10.1016/j.jbusres.2019.10.039

EIS (2018). European Innovation Scoreboard 2018. European Commission. Gaviria-Marin, M., Merigo, J. M., \& Popa, S. (2018). Twenty years of the Journal of Knowledge Management: A bibliometric analysis, Journal of Knowledge Management, 22(8), 1655-1687. https://doi.org/10. 1108/JKM-10-2017-0497

GOV (2013). Odluka o namjenskom višegodišnjem institucijskom financiranju znanstvene djelatnosti na javnim sveučilištima i javnim 
DRUŠ. ISTRAŽ. ZAGREB GOD. 30 (2021), BR. 4, STR. 807-829

DABIĆ, M. ET AL.: INTERNATIONALISATION... znanstvenim institutima u republici hrvatskoj u godinama 2013., 2014. i 2015. (Decision on earmarked multi-year funding for scientific activity at public universities and institutes in 2013, 2014 and 2015.), Official Gazette, No 69/2013.

GOV (2018). Odluka o programskom financiranju javnih visokih učilišta u Republici Hrvatskoj u akademskim godinama 2018./2019., 2019./ 2020., 2020./2021. i 2021./2022. (Decision on program funding of public higher education institutions in the Republic of Croatia in the academic years 2018/2019, 2019/2020, 2020/2021 and 2021/2022), Official Gazette, No 87/2018.

Grančay, M., Vveinhardt, J., \& Šumilo, Ē. (2017). Publish or perish: How central and eastern European economists have dealt with the ever-increasing academic publishing requirements 2000-2015. Scientometrics, 111(3), 1813-1837. https://doi.org/10.1007/s11192-0172332-z

Hebrang Grgić, I. (2020, March 30). Hrvatski časopisi u međunarodnim bazama podataka (Croatian journals in international databases). Universitas, Vol XII. No 125, p. 10. https://www.hrstud.unizg.hr/_news/ 39974/Universitas_125.pdf

Jokić, M. (2005). Bibliometrijski aspekti vrednovanja znanstvenog rada (Bibliometric aspects of the evaluation of scientific work). Sveučilišna knjižara.

Jokić, M. (2020). Productivity, visibility, authorship, and collaboration in library and information science journals: Central and Eastern European authors. Scientometric, 122, 1189-1219. https://doi.org/10.1007/ s11192-019-03308-4

Jokić, M., \& Lasić-Lazić, J. (2015). Vrednovanje znanstvenog rada u području društvenih znanosti na temelju časopisa kao medija znanstvenog komuniciranja (Evaluation of scientific work in the field of social sciences based on the journal as a medium of scientific communication). In I. Hebrang Grgić (Ed.), Hrvatski znanstveni časopisi: iskustva, mogućnosti, gledišta (Croatian scientific journals: Experiences, views, opportunities) (pp. 197-214). Školska knjiga.

Jokić, M., Mateljan, S., \& Petrović, N. (2017). Are the social sciences from the European post-socialist countries integrated in the "Western social sciences"? 16th International Conference on Scientometrics \& Informetrics Conference Proceedings (pp. 1676-1677). Wuhan, The International Society for Informetrics and Scientometrics (ISSI).

Jokić, M., Zauder, K., \& Letina, S. (2010). Croatian scholarly productivity 1991-2005 measured by journals indexed in Web of Science, Scientometrics, 83(2), 375-395. https://doi.org/10.1007/s11192-009-0071-5

Jokić, M., Zauder, K., \& Letina, S. (2012). Karakteristike hrvatske nacionalne i međunarodne znanstvene produkcije u društveno-humanističkim znanostima i umjetničkom području za razdoblje 1991 - 2005 (The features of Croatian national and international scholarly productivity in social sciences, arts and humanities 1991-2005). Institute for Social Research in Zagreb.

Kiessling, T., Vlačić, B., \& Dabić, M. (2021). Mapping the future of cross-border mergers \& acquisitions. IEEE Transactions on Engineering Management, 68(1), 212-222. https://doi.org/10.1109/TEM.2019.2954799

Macan, B., \& Petrak, J. (2015). Bibliometrijski pokazatelji za procjenu kvalitete znanstvenih časopisa (Bibliometric indicators for quality assessment of scientific journals). In I. Hebrang Grgić (Ed.), Hrvatski 
DRUŠ. ISTRAŽ. ZAGREB GOD. 30 (2021), BR. 4, STR. 807-829

DABIĆ, M. ET AL.: INTERNATIONALISATION... znanstveni časopisi: iskustva, mogućnosti, gledišta (Croatian scientific journals: Experiences, views, opportunities) (pp. 37-53). Školska knjiga.

Macan, B., Pikić, A., \& Mayer, M. (2012). (Inter)national orientation of Croatian social sciences and arts and humanities journals indexed in the Web of Science Database. Društvena istraživanja, 21(2), 505-521. https://doi.org/10.5559/di.21.2.11

Macan, B., Škorić, L., \& Petrak, J. (2020). David among Goliaths: Open access publishing in scientific (semi-)periphery. Learned Publishing, 33(4) 410-417. https://doi.org/10.1002/leap.1320

Marušić, A., \& Marušić, M. (2015). Znanstveni časopisi u Hrvatskoj: teška pitanja na koja nije teško odgovoriti (Scientific journals in Croatia: Difficult questions that are not difficult to answer). In I. Hebrang Grgić (Ed.), Hrvatski znanstveni časopisi: iskustva, mogućnosti, gledišta (Croatian scientific journals: Experiences, views, opportunities) (pp. 15-36). Školska knjiga.

Marušić, M., \& Marušić, A. (2014). The Croatian Medical Journal: Success and consequences. In K. Bennett (Ed.), The semiperiphery of academic writing discourses, communities and practices (pp. 210-221). Palgrave Macmillan. https://doi.org/10.1057/9781137351197_12

Moed, F. H., De Moya-Anegon, F., Guerrero-Bote, V., \& Lopez-Illescas, C. (2020). Are nationally oriented journals indexed in Scopus becoming more international? The effect of publication language and access modality. Journal of Informetrics, 14(2), 101011, https://doi.org/ 10.1016/j.joi.2020.101011

Moed, H. F., De Moya-Anegon, F., Guerrero-Bote, V., \& Lopez-Illescas, C. (2021). Corrigendum to "Are nationally oriented journals indexed in Scopus becoming more international? The effect of publication language and access modality". Journal of Informetrics 15(1), 101078. https://doi.org/10.1016/j.joi.2020.101078

Pajić, D. (2015). Globalization of the social sciences in Eastern Europe: Genuine breakthrough or a slippery slope of the research evaluation practice? Scientometrics, 102(3), 2131-2150. https://doi.org/10. 1007/s11192-014-1510-5

Petrić, M. (2011). Bibliometrics cum grano. Revija za sociologiju, 41(1), 99-114. https://doi.org/10.5613/rzs.41.1.6

Pilar (2019). Business report of the Ivo Pilar Institute (January 1 - December 31, 2019) Available at https://www.pilar.hr/2012/05/opci-akti/ (12th April 2020).

Prpić, K. (Ed.) (2008). Onkraj mitova o prirodnim i društvenim znanostima: sociološki pogled (Beyond the myths about the natural and social sciences: A sociological view). Institute for Social Research in Zagreb.

Prpić, K., \& Petrović, N. (2010), Croatian social scientists' productivity and a bibliometric study of sociologists' output. Sociologija i prostor, 48(3), 437-459. https://hrcak.srce.hr/index.php?show=clanak\& id_clanak_jezik $=100512 \& l a n g=e n$.

Račić, D., \& Švarc, J. (2020). Innovation country report 2019: High growth enterprises, innovation and productivity challenges - Croatia, 2020. Report for the European Commission.

Rialp, A., Merigó, J. M., Cancino, C. A., \& Urbano, D. (2019). Twenty-five years (1992-2016) of the International Business Review: A biblio- 
DRUŠ. ISTRAŽ. ZAGREB GOD. 30 (2021), BR. 4, STR. 807-829

DABIĆ, M. ET AL.: INTERNATIONALISATION... metric overview. International Business Review, 28(6), 101587. https:// doi.org/10.1016/j.ibusrev.2019.101587

Salager-Meyer, F. (2008). Scientific publishing in developing countries: Challenges for the future. Journal of English for Academic Purposes, 7(2), 121-132. https://doi.org/10.1016/j.jeap.2008.03.009

Štulhofer, A., Baćak, V., \& Šuljok, A. (2010). A parochial status of Croatian sociology? Revija za sociologiju, 40(1), 103-108.

Tomić-Koludrović, I. (2009). A view of the future: Sociology as a multiparadigmatic, reflexive and public science. Revija za sociologiju, 40[39] (3-4), 139-181.

Valenzuela, L. M., Merigo, J. M., Johnston, W. J., Nicolas, C., \& Jaramillo, J. F. (2017). Thirty years of the Journal of Business $\mathcal{E}$ Industrial Marketing: A bibliometric analysis. Journal of Business $\mathcal{E}$ Industrial Marketing, 32(1), 1-17. https://doi.org/10.1108/JBIM-04-2016-0079

Van Eck, N. J., \& Waltman, L. (2017). Citation-based clustering of publications using CitNetExplorer and VOSviewer. Scientometrics, 111(2), 1053-1070. https://doi.org/10.1007/s11192-017-2300-7

World Bank (2019). Analysis of the quality and coherence of the policy mix. World Bank Group, Croatia Country Office.

Zgrabljić Rotar, D., Jokić, M., \& Mateljan, S. (2018). The visibility of papers written by authors from European post-socialist countries as an indicator of integration into the EU legal system. Croatian Yearbook of European Law and Policy, 14(1), 135-160. https://doi.org/10.3935/cyelp. 14.2018.304

\section{Internacionalizacija znanstvenog publiciranja u Hrvatskoj kroz prizmu bibliografske analize časopisa Društvena istraživanja}

Marina DABIĆ

Ekonomski fakultet, Sveučilište u Zagrebu,

Zagreb, Hrvatska

Jadranka ŠVARC

Institut društvenih znanosti Ivo Pilar,

Zagreb, Hrvatska

Božidar VLAČIĆ

Católica Porto Business School and CEGE,

Universidade Católica Portuguesa, Porto, Portugal

Jasminka LAŽNJAK

Filozofski fakultet, Sveučilište u Zagrebu,

Zagreb, Hrvatska

Cili je ovog istraživanja dodatno rasvijetliti internacionalizaciju znanstvenoga publiciranja u Hrvatskoj kroz istraživanje temelieno na bibliometrijskoj analizi časopisa Društvena istraživania (DI). Prvi dio ovog istraživanja posvećen je bibliometrijskoj analizi DI od 
DRUŠ. ISTRAŽ. ZAGREB GOD. 30 (2021), BR. 4, STR. 807-829

DABIĆ, M. ET AL.:

INTERNATIONALISATION... internacionalizacijom znanstvenih časopisa u Hrvatskoj, oslanjajući se na kritičku analizu relevantne literature i bibliometrijskih karakteristika DI. Rezultati ovog istraživanja dovode u pitanje relevantnost postojeće znanstveno-izdavačke politike za doprinos kvaliteti istraživačkih radova i njihovoj internacionalizaciji. Istraživanje ima implikacije na uređivačku i izdavačku politiku, kao i na znanstvenu politiku općenito.

Ključne riječi: Društvena istraživanja, znanstveno publiciranje, Hrvatska, bibliometrijska analiza, internacionalizacija

\section{(c) (i) (3)}

Međunarodna licenca / International License:

Imenovanje-Nekomercijalno / Attribution-NonCommercial 